\title{
APLIKASI UJIAN ONLINE BERBASIS WEB DI SMA BHAKTI NUSANTARA PALEMBANG
}

\author{
Nyimas Sopiah ${ }^{1}$, Muhammad Theda Amanda ${ }^{2}$, Muhammad Theda Aminto ${ }^{3}$, \\ Alfi Brilian Al Mubarokah ${ }^{4}$, Yusriah Herawati ${ }^{5}$ \\ Universitas Bina Darma \\ Jalan Jenderal Ahmad Yani No.3 Palembang \\ Sur-el: nyimas.sopiah@binadarma.ac.id
}

\begin{abstract}
Palembang Bhakti Nusantara High School is one of the High Schools (SMA) that has used information technology in certain activities. Palembang's Bhakti Nusantara High School utilizes technology to facilitate teaching and learning by applying the Online Examination. At present, the exam still conducts tests using paper so that there is a need for further development to help and improve the effectiveness and efficiency of performance carried out in accordance with the business processes that run at the Bhakti Nusantara Palembang High School. This Online Examination is used to facilitate the management of master data needed to support the examination activities and the management of exam master data values. The software development method used is the web engineering method. This Online Examination implementation uses PHP, HTML, CSS, Javascript and MySQL Database Management System (DBMS).
\end{abstract}

Keywords: Applications, Online Testing, Web Engineering

\begin{abstract}
Abstrak: SMA Bhakti Nusantara Palembang adalah salah satu Sekolah Menengah Atas (SMA) yang sudah menggunakan teknologi informasi dalam beberapa aktivitas tertentu. SMA Bhakti Nusantara Palembang memanfaatkan teknologi untuk mempermudah proses belajar mengajar dengan menerapkan Ujian Online. Saat ini, Ujian masih melakukan ujian menggunakan kertas sehingga perlu adanya pengembangan lebih lanjut untuk membantu dan meningkatkan efektivitas dan efisiensi kinerja yang dilakukan sesuai dengan proses bisnis yang berjalan di SMA Bhakti Nusantara Palembang. Ujian Online ini digunakan untuk mempermudah dalam pengelolaan data-data master yang dibutuhkan dalam menunjang kegiatan ujian dan pengelolaan nilai data master ujian. Metode pengembangan perangkat lunak yang digunakan adalah metode web engineering. Implementasi Ujian Onlineini menggunakan bahasa pemrograman PHP, HTML, CSS, Javascript serta Database Management System (DBMS) MySQL.
\end{abstract}

Kata Kunci: Aplikasi, Ujian Online, Web Engineering

\section{PENDAHULUAN}

Saat ini perkembangan teknologi informasi sudah sangat pesat. Pemanfaatan teknologi telah mempengaruhi berbagai macam aspek kehidupan. Salah satunya teknologi informasi yang sudah memasuki dunia pendidikan mulai dari tingkat bawah hingga perguruan tinggi. Pada era teknologi informasi ini, dunia pendidikan sudah banyak menggunakan teknologi informasi dalam suatu aktivitas tertentu, salah satunya SMA Bhakti Nusantara Palembang.

SMA Bhakti Nusantara merupakan salah satu Sekolah Menengah Atas (SMA) yang terletak di Kota Palembang. SMA Bhakti Nusantara Palembang juga termasuk sekolah yang sudah menggunakan teknologi informasi dalam aktivitas tertentu. Akan tetapi dalam penggunaannya masih belum sepenuhnya menggunakan teknologiinformasi, terutama dalam proses belajar mengajar. 
Permasalahan yang dialami oleh SMA Bhakti Nusantara adalah dalam hal ujian harian pada sekolah tersebut masih menggunakan kertas dan nilai ujian masih diperiksa secara manual. Dikarenakan prosesnya masih manual, maka proses yang dilakukan membutuhkan waktu yang relatif cukup lama dan juga sering terjadi kesalahan pada hal tersebut.

Sistem ujian online merupakan salah satu bagian sistem informasi pendidikan jarak jauh melalui media teknologi internet [1].Oleh karena itu, perlu dibangun sebuah Aplikasi Ujian Onlineberbasis Web untuk mempermudah sekolah dalam mengelola data nilai ujian sehingga pihak sekolah tidak perlu lagi melakukannya secara manual. Selain itu, Aplikasi Ujian Online Berbasis Web juga mempermudah sekolah dalam melakukan seperti penjadwalan ujian, pemeriksaan ujian, serta pembuatan laporan.

Metode pengembangan perangkat lunakyang digunakan dalam membuat Aplikasi Ujian Online Berbasis Web adalah metode Web Engineering yang terdiri dari beberapa tahapan yaitu Customer Communication, Planning, Modelling, Construction, dan Deployment. Implementasi Aplikasi Ujian Online Berbasis Web ini menggunakan bahasa pemrograman PHP, HTML, CSS, Javascript serta Database Management System (DBMS) MySQL.Hypertext Preprocessor (PHP) adalah software yang diperoleh secara gratis karena bersifat open source dan dapat digunakan berbagai jenis platform sistem operasi [2]. MySQL adalah software atau program Database Server [3]. Sedangkan SQL adalah bahasa pemrogramannya, bahasa permintaan (query) dalam database server termasuk dalam MySQL itu sendiri. MySQL merupakan database server yang paling sering digunakan dalam pemograman PHP [4].

\section{METODOLOGI PENELTIAN}

\subsection{Metode Pengumpulan Data}

Pengumpulan data dilakukan dengan berbagai macam cara, yaitu pertama adalah pengamatan (observasi), yaitu metode pengumpulan data dengan cara melihat dan mengunjungi objek yang diteliti. Untuk mendapatkan data maka penulis melakukan pengamatan secara langsung di SMA Bhakti Nusantara Palembang. Kedua adalah wawancara (interview) yaitu metode pengumpulan data yang dilakukan dengan cara tanya jawab secara langsung kepada pihak-pihak yang terkait. Dalam hal ini penulis melakukan sesi tanya jawab kepada pihak SMA Bhakti Nusantara Palembang, terutama tata usaha, guru dan siswa. Ketiga adalah studi pustaka atau studi literatur yaitu metode pengumpulan data dengan cara mempelajari teori-teori yang berkaitan pada penulisan. Untuk mendapatkan data-data yang bersifat teoritis maka penulis melakukan pengumpulan data dengan membaca dan mempelajari buku-buku, jurnal, makalah ataupun referensi lain yang berhubungan dengan masalah yang dibahas.

\subsection{Metode Pengembangan Aplikasi}

Metode pengembangan perangkat lunak yang digunakan dalam membangun Aplikasi Ujian OnlineBerbasis Web di SMA Bhakti 
Nusantara Palembang adalah metode web engineering. Adapun beberapa tahapan dalam metode web engineering [5]:

\section{1) Customer Communication}

Tujuan dari customer communication adalah adalah untuk mendeskripsikan masalah web aplikasi yang akan dicari pemecahan masalahnya.

2) Planning

Perencanaan terdiri dari definisi task dan timeline schedule pada periode waktu tertentu dalam pembuatan web aplikasi.

3) Modelling

Tujuan dari tahap ini adalah untuk menjelaskan yang berkaitan dengan proses model apa yang digunakan dan desain yang akan digunakan pada web aplikasi.

4) Construction

Berkaitan dengan tools dan teknologi yang diaplikasikan untuk membangun web aplikasi.

5) Deployment

Penggunakan web aplikasi yang dibuat untuk operational environmentnya, terkirim ke end-user dan mengevaluasi secara berkala web aplikasi tersebut.

\subsection{Studi Kelayakan Sistem}

Ada beberapa kelayakan yang menentukan apakah sistem yang dibuat layak untuk dikembangkan atau tidak. Pertama adalah kelayakan teknik. kelayakan teknik ini ditinjau dari sisi teknologi, dimana teknologi di dalam pengembangan sistem ini mudah didapatkan dan pemakaiannya mudah sehingga pengembangan sistem layak untuk dikembangkan. Teknologi yang dimaksud adalah teknologi perangkat keras dan perangkat lunak. Perangkat Keras (Hardware) yang digunakan adalah Laptop Acer Aspire ES 14, RAM 2GB, Harddisk 500GB, dan Printer Canon G2010. Sedangkan perangkat lunak terdiri dari Sistem Operasi Windows 10, Google Chrome sebagai web browser untuk membuka aplikasi. Microsoft Word sebagai aplikasi untuk pengolahan data untuk penulisan penulisan, Microsoft Visiosebagai aplikasi untuk membuat Data Flow Diagram dan Entity Relationship Digram, dan XAMPP sebagai web server dalam pembuatan aplikasi.

\subsection{Penelitian Terdahulu}

Penelitian yang terkait dengan Proses belajar online sudah banyak dilakukan. Beberapa yang menjadi referensi dalam penelitian ini adalah sebagai berikut; Penelitian yang berjudul Perangkat lunak tes pendahuluan perkuliahan di laboratorium komputer Universitas Bina Darma yang menghasilkan perangkat lunak untuk membantu perkuliahan di laboratorium. Perangkat lunak ini digunakan untuk melakukan tes setiap terjadi perkuliahan dimana digunakan untuk mengetahui kemampuan mahasiswa di perkuliahan sebelumnya [6].

Penelitian lain dilakukan oleh Dela Aprilia Wibawa dan Aqwam Rosadi Kardian [7]yang menghasilkan website ujian online untuk SMA Pondok Karya Pembangunan (PKP) Jakarta Islamic School (JIS) dengan metode Linear Congruental Generator menggunakan perangkat lunak macromedia dreamweaver CS6 dan XAMPP yang merupakan gabungan dari apache web server, PHP dan MySQL dan browser google chrome. Sehingga dapat memudahkan pelaksanaan ujian dibandingkan 
menggunakan kertas dan pemeriksaan manual, karena dengan adanya aplikasi ujian online dapat membantu dalam pelaksaan ujian.

Selain itu penelitian yang dilakukan oleh Sugiarti dan Irawatimenghasilkan aplikasi untuk membantu ujian secara online. Aplikasi ini dapat membantu guru untuk mendapatkan hasil ujian tanpa koreksi secara manual, karena telah dihasilkan dari sistem yang teraplikasi [8].

\section{HASIL DAN PEMBAHASAN}

Metode yang digunakan dalam mengembangkan aplikasi ini adalah dengan menerapkan web engineering. Metode ini terdiri dari beberapa tahapan yaitu:

\subsection{Customer Communication}

Pada tahap customer communication ini terdiri dari 2 tahap, yaitu formulation dan business analysis. Penulis melakukan observasi pada SMA Bhakti Nusantara Palembang dan juga melakukan interview dengan pihak sekolah yaitu dengan tata usaha, guru dan siswa.

Tahap formulation ini, penulis menentukan tujuan, kebutuhan dan siapa saja yang menggunakan aplikasi ini. Tujuan dari membangun aplikasi adalah untuk menghasilkan perangkat lunak ujian onlineyang dapat mempermudah guru dan siswa dalam melakukan ujian pada SMA Bhakti Nusantara Palembang. Kebutuhan aplikasinya adalah untuk dapat menghasilkan suatu sistem ujian yang baru tanpa membutuhkan waktu yang relatif lama, karena aplikasi yang dihasilkan sudah menggunakan teknologi informasi. Pengguna yang terlibat dalam membangun aplikasi ini adalah tata usaha, guru dan siswa.

Pada tahap business analysis, penulis menguraikan kerja dari sistem yang ada saat ini. Pertama-tama, Guru harus membuat soal ujian terlebih dahulu dengan menggunakan Microsoft Word. Soal yang dibuat ditentukan oleh masingmasing guru yang mengajar. Setelah selesai dibuat menggunakan Microsoft Word, soal ujian tersebut kemudian dicetak menggunakan printer. Untuk memulai ujian tersebut, Siswa dan Guru harus memasuki ruang kelas terlebih dahulu.

Guru membagikan soal ujian yang telah dicetak tadi. Adapun beberapa Guru lainnya hanya menyebutkan soal ujian kepada Siswa. Siswa menjawab soal ujian dengan menggunakan kertas satu lembar dan kemudian menuliskan jawabannya pada kertas tersebut. Setelah selesai menjawab atau waktu yang diberikan Guru telah habis, maka Siswa harus mengumpulkan kertas jawaban mereka kepada Guru tersebut.

Guru yang mengajar mengoreksi jawaban Siswa dari kertas jawaban yang telah dikumpulkan sebelumnya. Terakhir, hasil ujian yang telah dikoreksi oleh Guru tadi diberikan kepada masing-masing Siswa.

Berdasarkan uraian di atas, masalah yang terjadi adalah terlalu banyak dokumentasi yang harus dikumpulkan (kertas ujian). Kemudian Guru mesti mengoreksi lembar jawaban siswa, artinya belum dilakukan secara otomatis. Berdasarkan hal itulah, maka perlu dikembangkan sistem yang terkomputerisasi dengan membuat website ujian online. 


\subsection{Planning}

Pada tahapan Planning, semua tahapan yang dilakukan menggunakan metode web engineering ini harus dijadwalkan dan ditentukan waktunya untuk memperjelas waktu dalam penelitian ini. Jadwal dilakukan penelitian ini dilakukan dari bulan September sampai dengan Januari 2019.

\subsection{Modelling}

Tahap ini merupakan tahap perancangan perangkat lunak. Salah satu alat bantu yang digunakan dalam penelitian ini adalah dengan membuat Data Flow Diagram, Entity Relationship Diagram dan Desain Database.

\section{1) Data Flow Diagram (DFD)}

Data Flow Diagram adalah suatu diagram yang mengambarkan aliran data dari sebuah proses atau sistem. Gambar 1 merupakan Diagram Konteks yang mengambarkan keseluruhan input, proses dan output pada ujian onlineberbasis web.

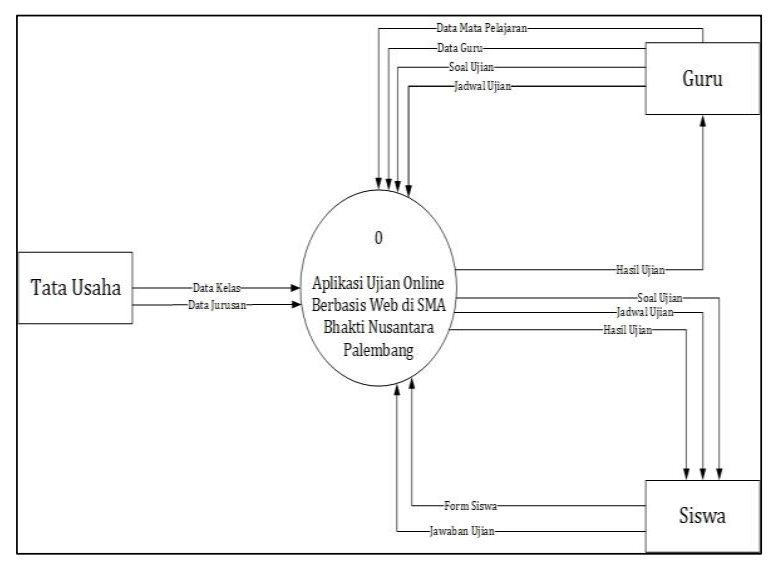

\section{Gambar 1. Diagram Context}

Gambar 2 merupakan Data Flow Diagramlevel 1 yang menggambarkan beberapa proses seperti kelola data, kelola ujian, dan laporan. Setiap proses sudah dijelaskan secara umum melalui DFD level 1 ini.

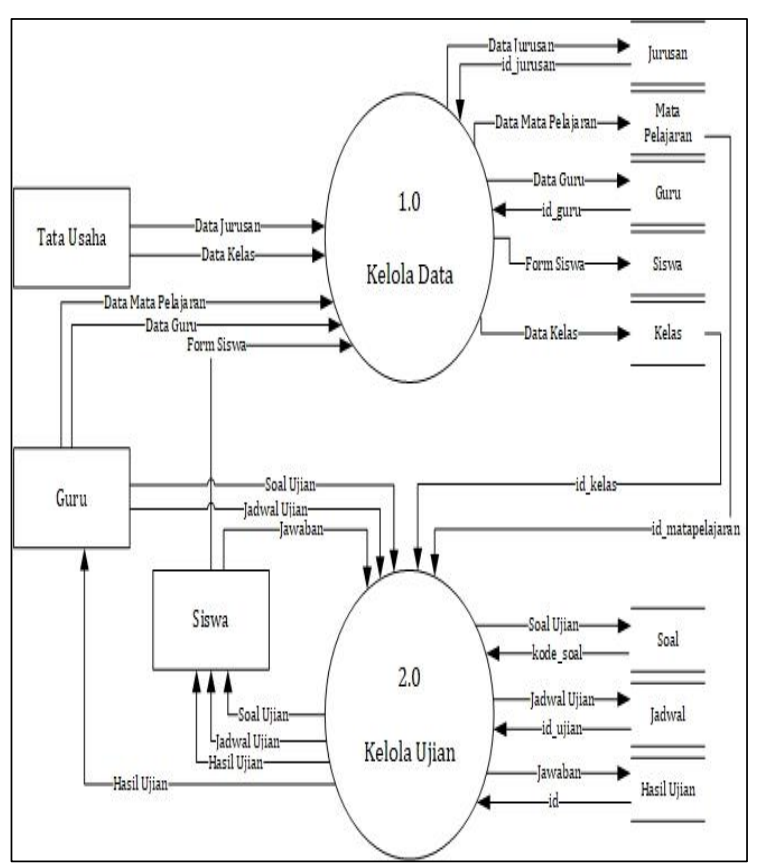

\section{Gambar 2. DFD Level 1}

\section{2) Entity Relationship Diagram (ERD)}

Setelah selesai membuat Data Flow Diagram, maka pemodelan selanjutnya adalah dengan membuat Entity Relationship Diagram(ERD). ERD adalah pemodelan basis data yang biasa digunakan dalam pengembangan sistem informasi, ERD juga bertujuan untuk menentukan hubungan satu entitas dengan entitas lainnya yang saling berhubungan.

Gambar 3 merupakan Entity Relationship Diagram yang menggambarkan hubungan relasi tiap-tiap entitas pada SMA Bhakti Nusantara Palembang. 


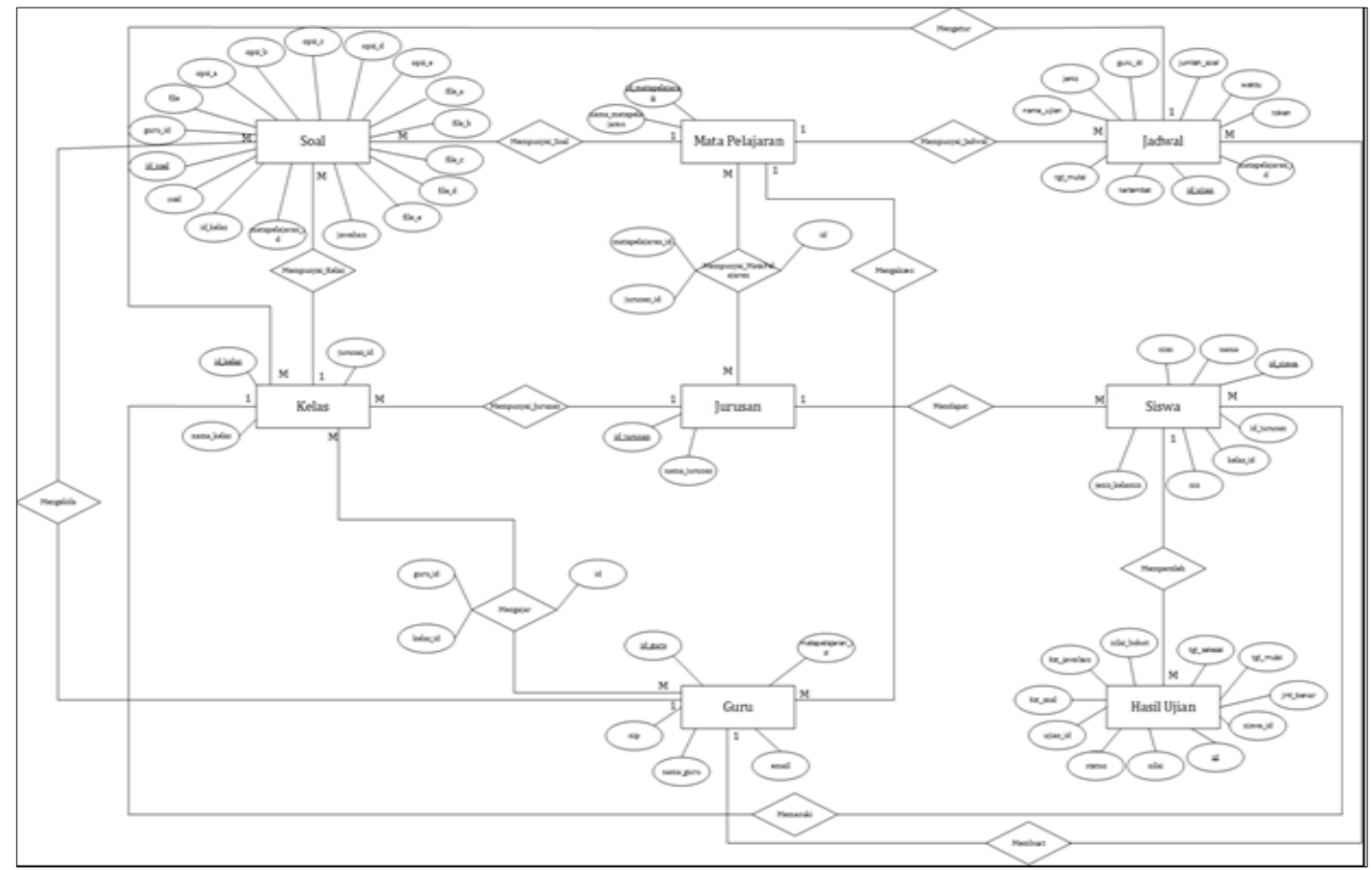

Gambar 3. Entity Relationship Diagram(ERD).

\subsection{Construction}

Construction merupakan tahap untuk membangun aplikasi ujian online berbasis web pada SMA Bhakti Nusantara Palembang. Aplikasi yang dibangun menggunakan bahasa pemrograman PHP dan database MySQL. Untuk mengakses aplikasi ini ada beberapa pemakai yang dapat melakukannya, yaitu tata usaha (orang yang mengelola seluruh data master), guru (orang yang membuat soal dan jadwal ujian), dan siswa (orang yang melakukan ujian).

Untuk pengguna tata usaha terdiri dari beberapa tampilan yaitu dashboard, data jurusan, tambah data jurusan, ubah data jurusan, data kelas, tambah data kelas, ubah data kelas, data mata pelajaran, tambah data mata pelajaran, ubah data mata pelajaran, data guru, tambah data guru, ubah data guru, data siswa, tambah data siswa, ubah data siswa, relasi kelas-guru, relasi jurusan-mata pelajaran, dan bank soal.

Implementasi Aplikasi Ujian Online Berbasis Web pada SMA Bhakti Nusantara
Palembang.Pertama-tama, Tata Usaha harus melakukan login terlebih dahulu ke dalam aplikasi.

Gambar 4 merupakan menu login yang akan ditampilkan pada pengguna tata usaha, guru, dan siswa.

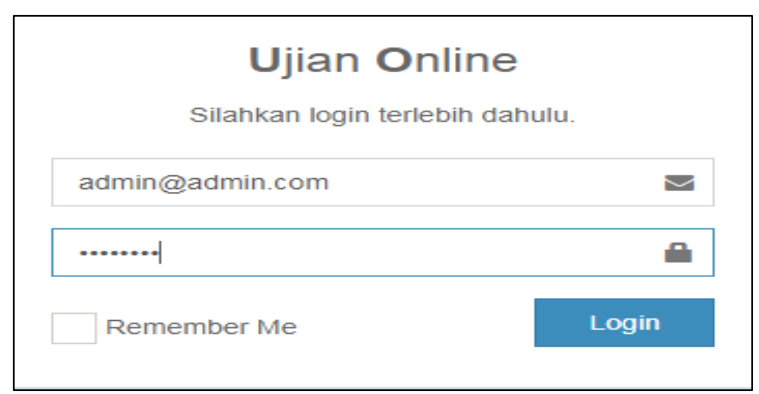

\section{Gambar 4. Tampilan Login}

Berikut akan ditampilkan berdasarkan pengguna website.

\section{1) Tata Usaha}

Setelah melakukan login, tata usaha akan masuk ke halaman dashboard yang berisi informasi mengenai banyaknya jurusan, kelas, mata pelajaran, guru, siswa. 
Gambar 5 merupakan menu dashboard yang ditampilkan pada pengguna tata usaha.

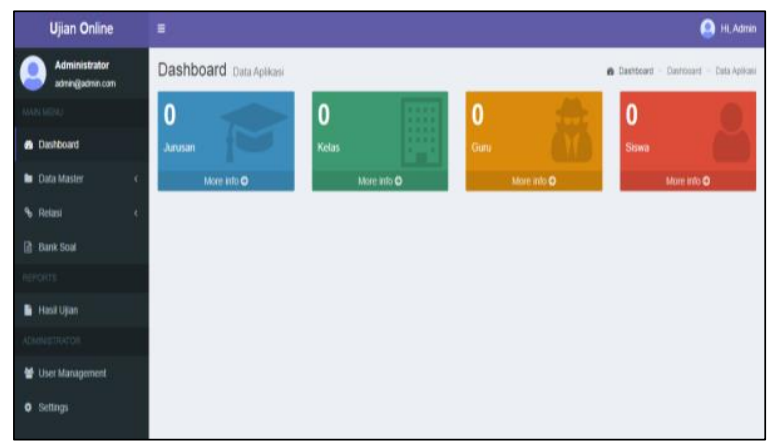

\section{Gambar 5. Tampilan Dashboard Tata Usaha}

Tata Usaha diharuskan menginputkan data master terlebih dahulu. Data master terdiri dari data jurusan, data kelas, data mata pelajaran, data guru dan data siswa. Gambar 6 merupakan menu tambah data jurusan yang ada pada pengguna tata usaha. Data jurusan berguna untuk menentukan jurusan mana siswa berasal.

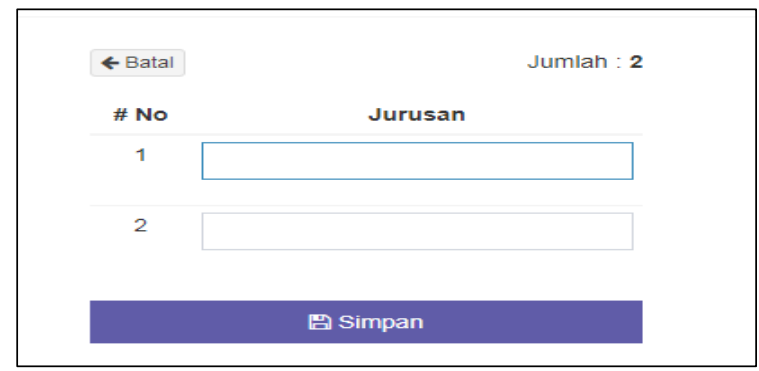

\section{Gambar 6. Tampilan Tambah Jurusan}

Gambar 7 merupakan menu tambah data kelas yang ada pada pengguna tata usaha. Data kelas merupakan data harus dimasukkan, karena data ini akan dikelompokkan sesuai dengan jurusan dan kelas masing-masing siswa.

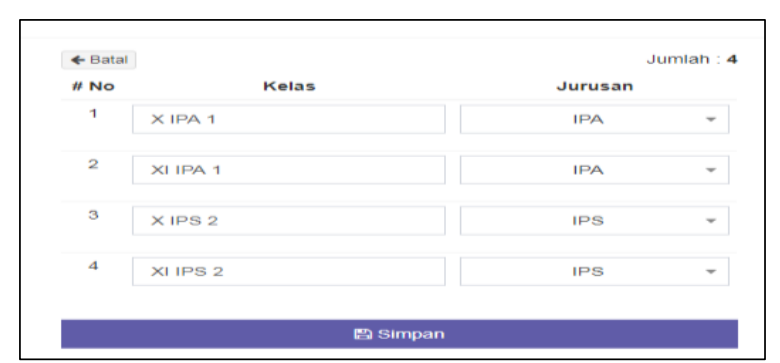

Gambar 7. Tampilan Tambah Kelas
Gambar 8 merupakan menu tambah data mata pelajaran yang ada pada pengguna tata usaha. Mata pelajaran merupakan data yang harus dimasukkan di setiap ujian, karena data ini berguna untuk memilih mata pelajaran apa yang akan diujikan.

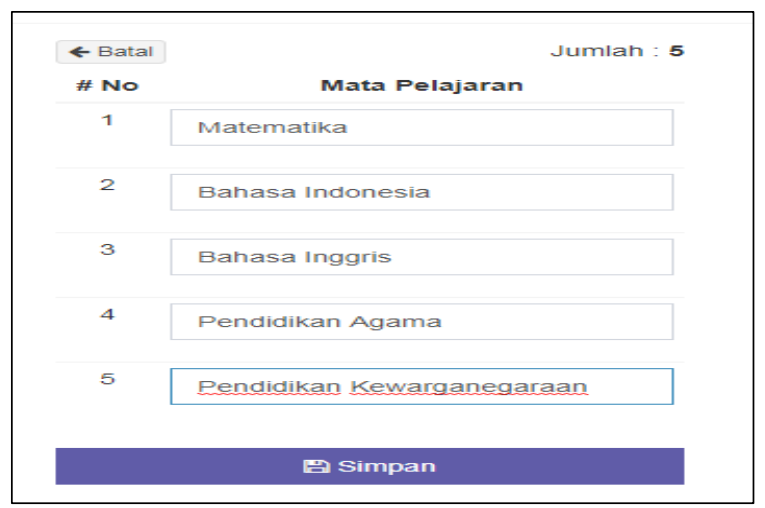

\section{Gambar 8. Tampilan Tambah Mata Pelajaran}

Gambar 9 merupakan menu tambah data guru yang ada pada pengguna tata usaha. Data guru merupakan data master untuk men-filter data yang diajarkan oleh guru.

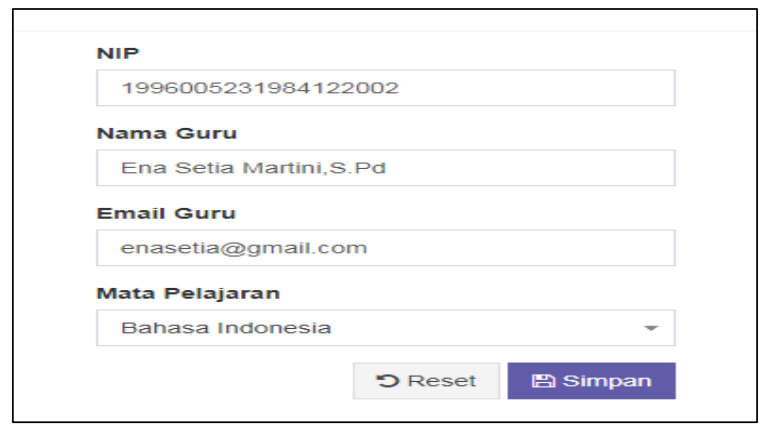

Gambar 9. Tampilan Tambah Guru

Gambar 10 merupakan menu tambah data siswa yang ada pada pengguna tata usaha. Data siswa juga diperlukan sebagai data master, jika data siswa tidak dimasukkan, maka siswa tidak akan dapat masuk ke aplikasi ini. 


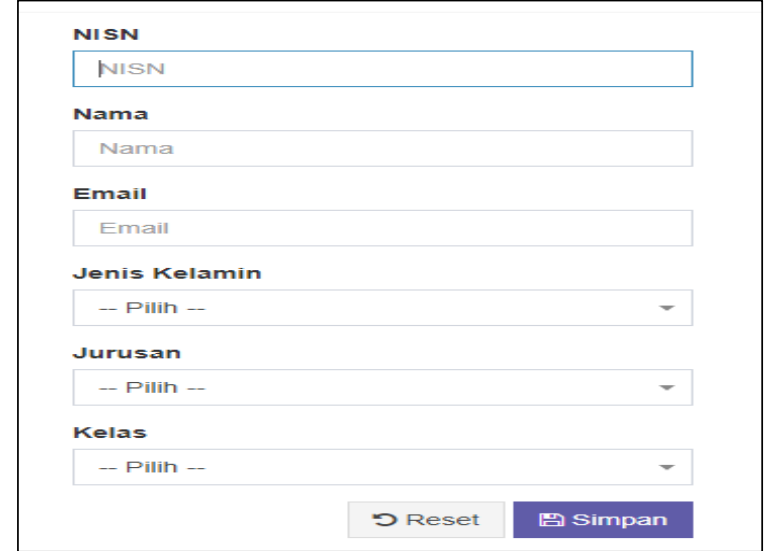

Gambar 10. Tampilan Tambah Siswa

Setelah memasukkan semua data master, maka data master tersebut akan tampil dalam bentuk tabel di tiap masing-masing master data.

Setelah itu tata usaha harus melakukan aktivasi guru dan siswa yang ada pada menu data guru dan data siswa.Gambar 11merupakan menu yang menampilkan aktivasi guru yang dimana email digunakan sebagai username dan nip digunakan sebagai password untuk melakukan login.

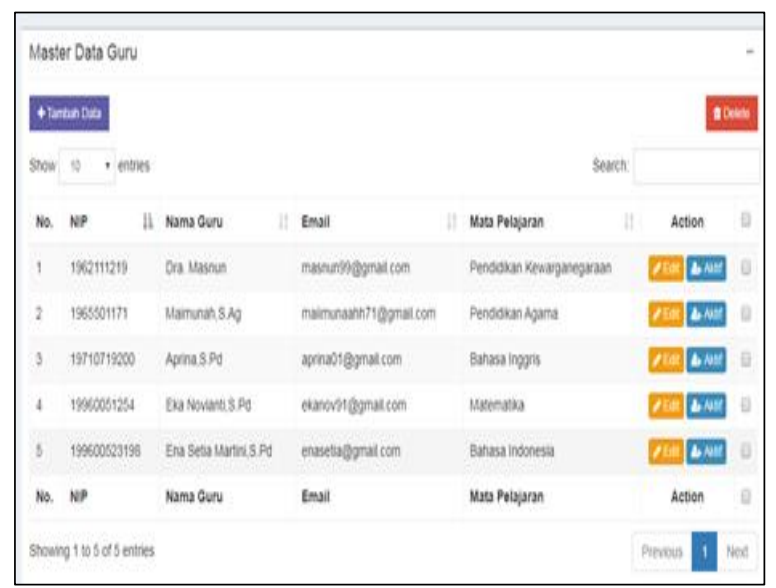

Gambar 11. Tampilan Data Guru

Gambar 12 merupakan menu yang menampilkan aktivasi siswa yang dimana email digunakan sebagai username dan NISN digunakan sebagai password untuk melakukan $\operatorname{login}$.

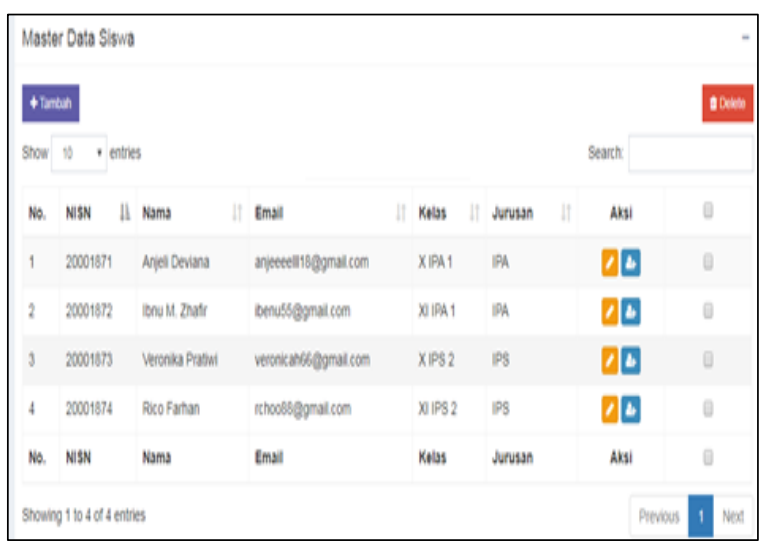

\section{Gambar 12. Tampilan Data Siswa}

Selanjutnya mengatur relasi kelas-guru dan mata pelajaran-jurusan. Gambar 13 merupakan menu yang menampilkan hubungan relasi antara kelas dengan guru.

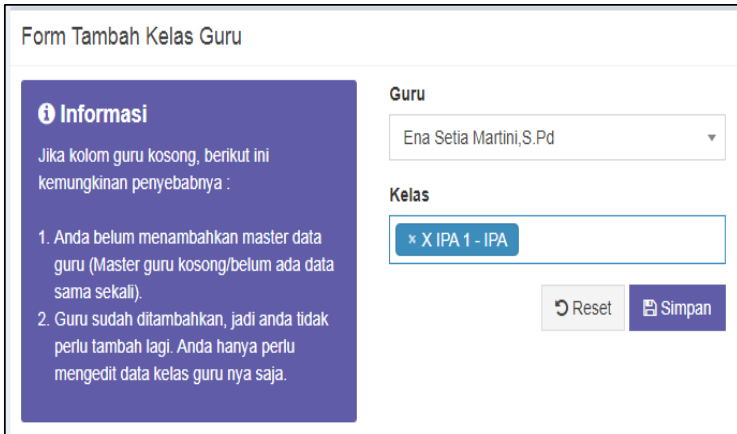

\section{Gambar 13. Tampilan Relasi Kelas - Guru}

Gambar 14 merupakan menu yang menampilkan hubungan relasi antara mata pelajaran dengan jurusan.Jadi setiap jurusan mempunyai mata pelajaran sendiri.

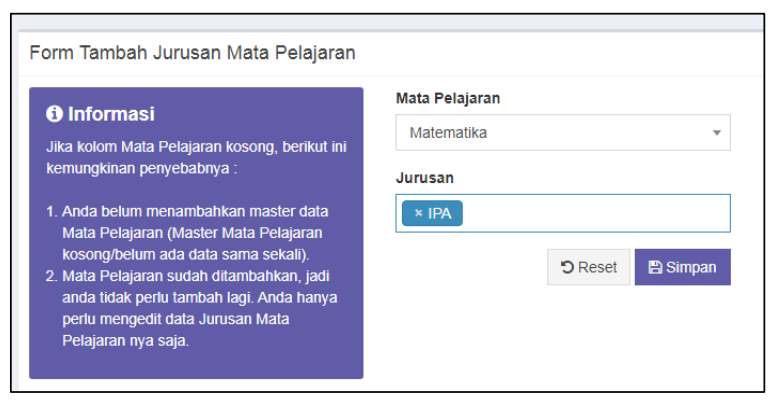

Gambar 14. Tampilan Relasi Mata PelajaranJurusan 


\section{2) Guru}

Setelah semua data master dan relasi telah dilakukan semuanya, guru dapat melakukan login ke dalam aplikasi dan akan masuk ke dalam aplikasi pengguna guru. Gambar 15 merupakan menu dashboard pada guru yang menampilkan informasi mengenai identitas guru.

\begin{tabular}{|ll|}
\hline Informasi Akun & \\
Nama & Aprina,S.Pd \\
NIP & 19710719200 \\
Email & aprina01@gmail.com \\
Mata Pelajaran & Bahasa Inggris \\
Daftar Kelas & $1 . \times$ IPS 2 \\
\hline
\end{tabular}

\section{Gambar 15. Tampilan Dashboard Guru}

Setelah melakukan login menggunakan akun guru, guru dapat melakukan pembuatan soal ujian.Gambar 16 merupakan menu tambah data soal yang ada pada pengguna guru.

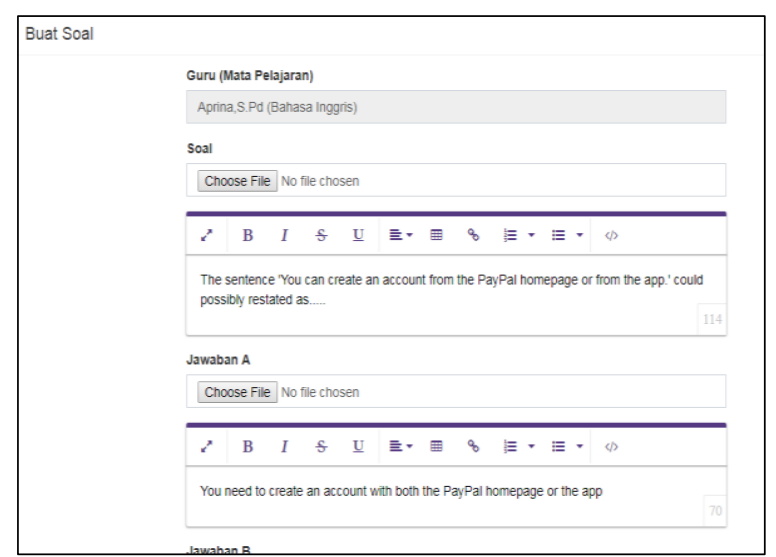

Gambar 16. Tampilan Tambah Soal

Gambar 17 merupakan menu data soal yang telah dibuat sebelumnya yang ada pada pengguna guru.

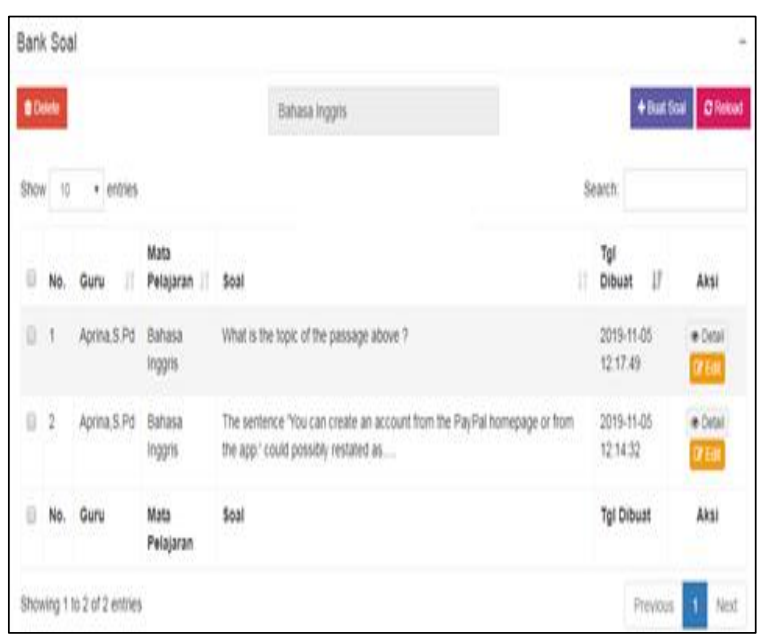

Gambar 17. Tampilan Menu Soal

Setelah guru membuat soal ujian, guru juga dapat melakukan penjadwalan ujian sesuai dengan mata pelajaran dan kelas yang mereka pilih.

Gambar 18 merupakan menu tambah jadwal ujian digunakan untuk penjadwalan ujian untuk siswa.

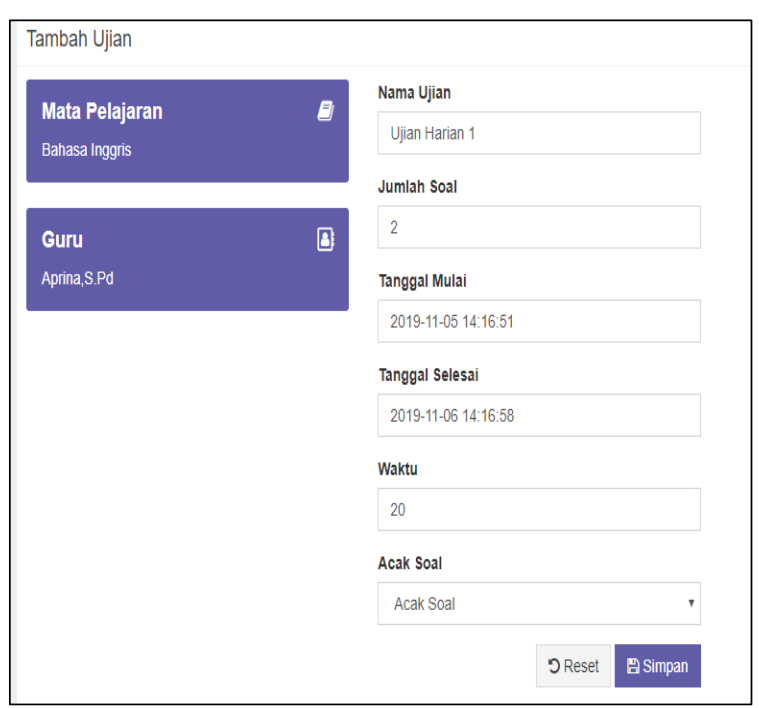

Gambar 18. Tampilan Tambah Jadwal

Gambar 19 merupakan menu data jadwal ujian yang telah dibuat. Jadwal ini berguna untuk siswa yang akan melakukan ujian. 


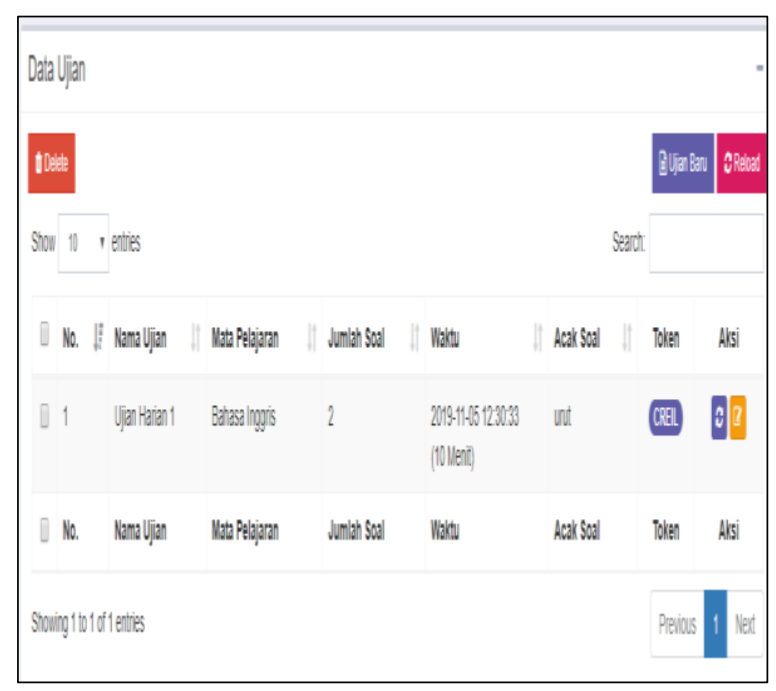

Gambar 19. Tampilan Jadwal Ujian

\section{3) Siswa}

Setelah guru telah melakukan penjadwalan ujian, siswa harus melakukan login untuk masuk ke menu pengguna siswa.

Gambar 20 merupakan menu dashboard yang menampilkan infromasi mengenai identitas siswa yang ada pada pengguna siswa.

\begin{tabular}{|ll|}
\hline Informasi Akun & \\
NIM & 20001874 \\
Jenis Kelamin & Rico Farhan \\
Email & rchoo88@gmail.com \\
Jurusan & IPS \\
Kelas & XI IPS 2 \\
\hline
\end{tabular}

Gambar 20. Tampilan Dashboard Siswa

Setelah login akun siswa, siswa dapat mengikuti ujian yang ada pada pada menu ujian. Gambar 21 merupakan menu yang menampilkan ujian yang telah dibuat sebelumnya.

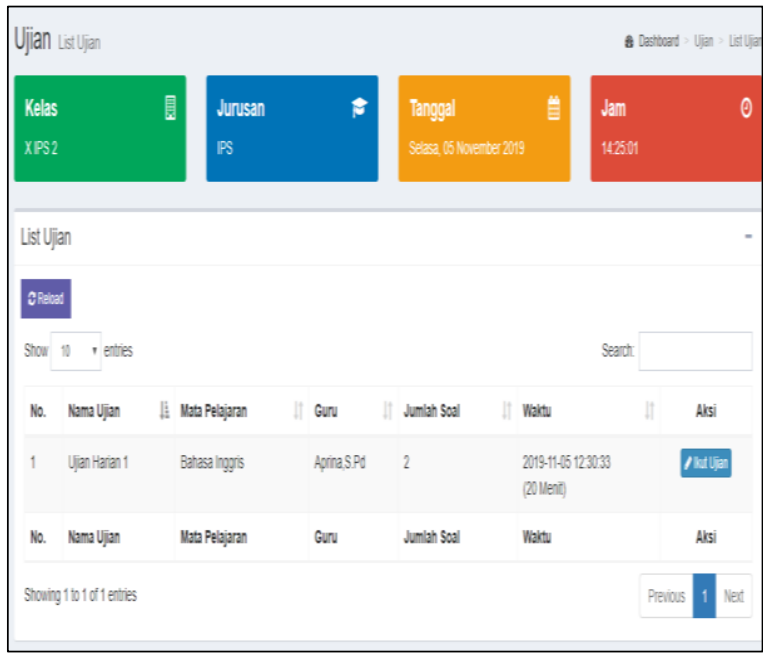

Gambar 21. Tampilan Jadwal Ujian

Setelah mengklik ikut ujian, maka akan tampil menu informasi mengenai ujian. Gambar 22 merupakan menu yang menampilkan informasi ujian, seperti lama waktu ujian, token dan lain-lain.

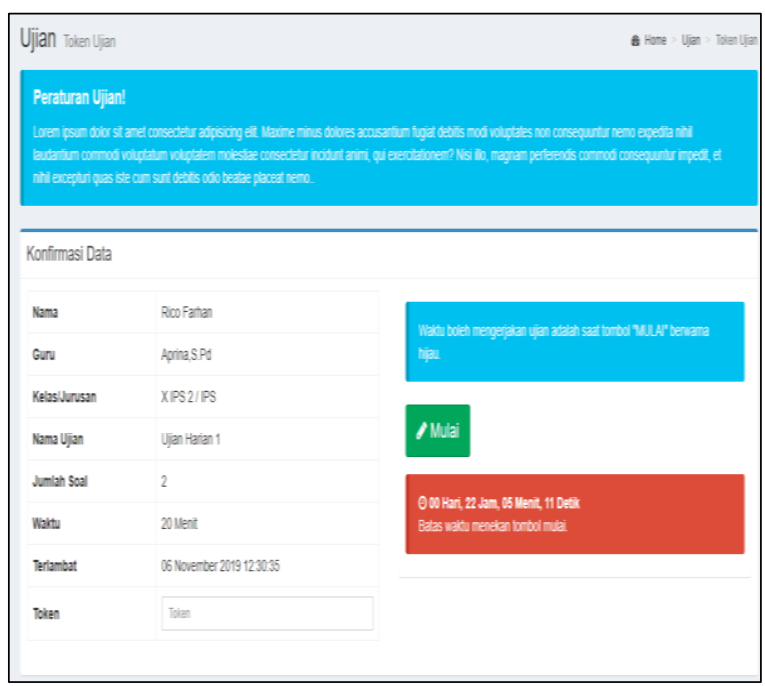

Gambar 22. Tampilan Konfirmasi Ujian

Setelah memasukkan token, siswa dapat menjawab ujian. Gambar 23 merupakan tampilan yang menampilkan soal ujian dan siswa dapat menjawab soal ujian. 


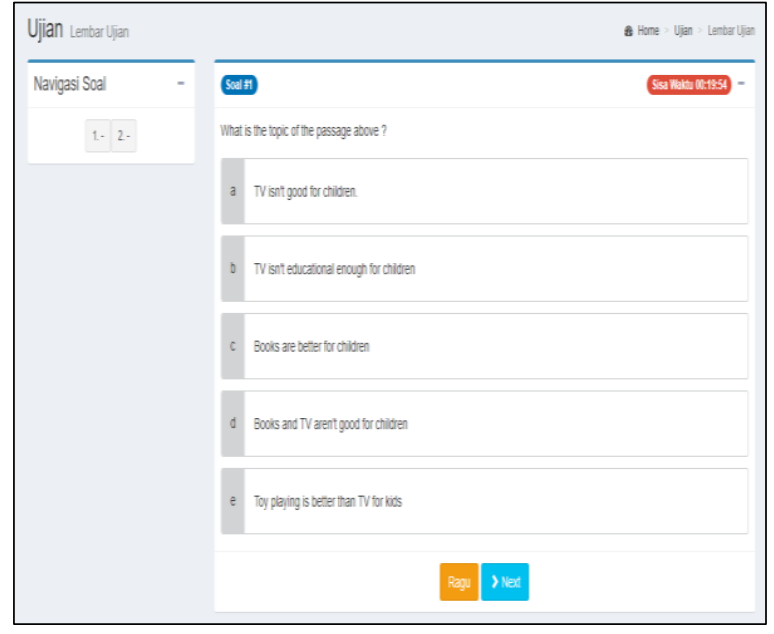

Gambar 23. Tampilan Soal dan Jawaban Ujian

Setelah melakukan ujian, siswa dapat melihat hasil ujian.Gambar 24 merupakan tampilan hasil ujian siswa pada pengguna siswa.

\begin{tabular}{|ll|}
\hline & Hasil Ujian \\
& \\
Data Peserta & \\
NIM & \\
Nama & Roo01874 \\
Kelas & Xico Farhan \\
Jurusan & XPS 2 \\
Data Ujian & \\
Mata Pelajaran & \\
Nama Ujian & Bahasa Inggris \\
Jumlah Soal & Ujian Harian 1 \\
Hasil Ujian & 2 \\
Jawab Benar & \\
Nilai & 1 \\
& 50.00 \\
\hline
\end{tabular}

\section{Gambar 24. Tampilan Hasil Ujian Siswa}

Guru juga dapat melihat hasil ujian keseluruhan siswa yang ada pada menu hasil ujian. Gambar 24 merupakan tampilan hasil ujian pada pengguna guru

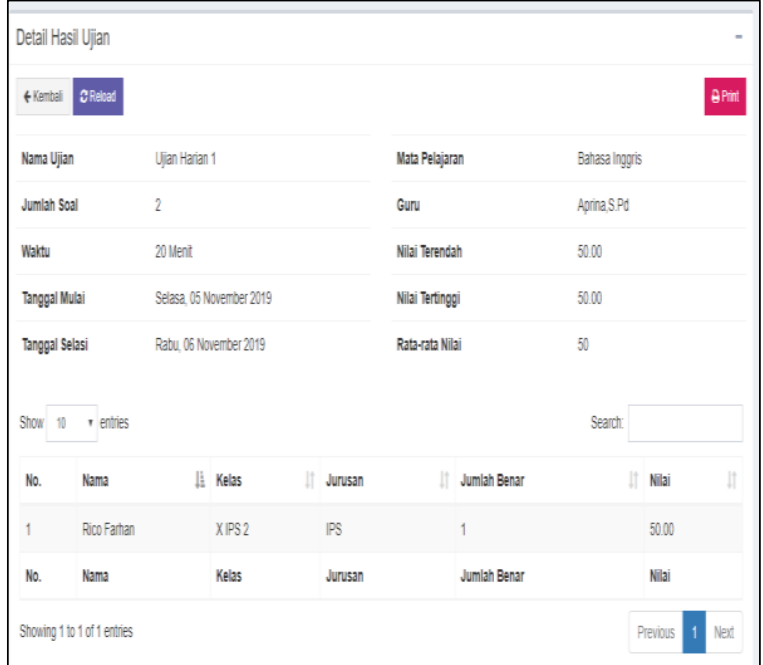

Gambar 24. Tampilan Hasil Ujian

\subsection{Deployment}

Tahap deployment merupakan sebuah tahapan yang memberikan suatu peningkatan pada WebApp secara berkala untuk user dan mengevaluasi serta memberikan umpan balik. Tahap ini dilakukan setelah aplikasi telah berjalan dengan baik atau digunakan pada SMA Bhakti Nusantara Palembang. Penelitian ini masih dalam proses implementasi, jadi sejauh implementasi yang telah dilakukan, pengguna (tata usaha, guru dan siswaa) sudah dapat menggunakan aplikasi ini dengan baik.

\section{KESIMPULAN}

Berdasarkan dari hasil penelitian yang telah dilakukan pada SMA Bhakti Nusantara Palembang, maka dapat disimpulkan, pertama telah dihasilkan aplikasi ujian online pada SMA Bhakti Nusantara Palembang tersebut. Kedua, ujian online dapat dilakukan secara online sehingga memudahkan siswa dalam melakukan ujian selain itu dengan adanya ujian online siswa tidak perlu lagi menulis soal dan jawaban ujian. 


\section{DAFTAR PUSTAKA}

[1] Yonatan Aji Setiawan, "Pembutan Sistem Ujian Online Berbasis Web".Digital Library UNS. [Online]. Available: https://digilib.uns.ac.id/dokumen/abstrak/32 787/Pembuatan-sistem-ujian-onlineberbasis-web. [Accessed: 05-Aug-2019].

[2] Franky Rawung,Buku Pintar Aplikasi SMS dengan PHP dan MySQL.Yogyakarta:Gava Media, 2017.

[3] Bunafit Nugroho,Dasar Pemograman Web PHP-MySQL dengan Dreamweaver. Yogyakarta: Gava Media. 2013.

[4] I Komang Setia Buana. Jago Pemrograman PHP. Jakarta: Dunia Komputer. 2014.

[5] Roger SPressman, Software Engineering: A Practitioner's Approach.New York: McGraw-Hill. 2010.

[6] Nyimas Sopiah, "Perangkat Lunak Tes Pendahuluan Perkuliahan di Laboratorium Komputer Universitas Bina Darma," in 2017Prosiding SNAPP: Sains dan Teknologi, Volume 7 Nomor 1, 2017, pp . 98-105.

[7] DelaAprilia Wibawa dan AqwamRosadi, Kardian,"Aplikasi Ujian Online untuk SMA PKP JIS dengan Metode Linear Congruental Generator (LCG) Berbasis Website,"Jurnal Ilmiah Komputasi, Volume 16 No 2, pp 145-150, 2017.

[8] Sugiarti dan Irawati, "Aplikasi Ujian Akhir Semester Berbasis Online pada SMK Mandiri Makassar,"Jurnal Balireso Vol. 4, No. 1, pp 47-60, 2019. 